\title{
WATER ABSORPTION CAPACITY COEFFICIENT AND MASS MOISTURE OF RAMMED EARTH MATERIAL
}

\author{
Barbora Mužíková*, Tereza Otcovská, Pavel Padevět
}

\author{
Czech Technical University in Prague, Faculty of Civil Engineering, Thákurova 7, 16629 Prague 6, Czech \\ Republic \\ * corresponding author: barbora.muzikova@fsv.cvut.cz
}

\begin{abstract}
This article presents the development of mass moisture of rammed earth material and determines the water absorption capacity coefficient for rammed earth with illite-kaoline clay. Specimens of two prescriptions were rammed in the moulds. They were settled in the box with soft foam that was moistened. The level of moistening was kept constant. The specimens were regularly measured and weighted. Two measuerements were carried out - one of montmorillonite clay during 13 days and one of illite-kaoline clay during three hours. The development of moisture increase was captured and the water absorption capacity coefficient for illite-kaoline clay was determined and compared to coefficients of common building materials.
\end{abstract}

KEYWORDS: Rammed earth, illite-kaoline clay, mass wetness, water absorption capacity coefficient.

\section{INTRODUCTION}

This article presents earth material as a modern building material based on the long history of using, but in last centuries it was replaced by modern materials. The material characteristics were never fully researched due to the replacement. The demand for the earth material is increasing nowadays following the principles of sustainable buildings development [1, 2].

The main advantages of using earth as a building material are good air humidity balance, lower costs for material and construction, and also the fact that the earth based material has a positive effect on human health. Rammed earth is accessible, environmentally friendly and suitable for low-cost building in person. According to the sustainable buildings development not only the mechanical properties are important in the structure design. The quality of building material is also given by economic and socio-cultural criteria. For example the rammed earth primary energy consumption connected with production of building material is about $44 \mathrm{kWh} / \mathrm{m}^{3}$. This is $18 \times$ less than for prefabricated concrete material 36 ] . The increasing interest in unburned earth material can be seen in the sales of unburned clay bricks in portfolio of Heluz company shown in Table 1 [7.

The mechanical properties of the unburned earth depend mainly on the composition and the method of processing. The basic methods of using earth are mudwalls, rammed earth, earth bricks, earth infill in a timber frame construction etc. The material which the research is focusing on is rammed earth. Rammed earth walls are constructed by the compacting (ramming) of moistened subsoil into place between temporary framemwork panels.

The process of building is shown in Figure 1 First of all, the reinforced plywood framework is built and then the first layer moist earth (mixture of sand, gravel

\begin{tabular}{cc}
\hline Year & Sold unburned bricks [pcs] \\
\hline 2010 & 700 \\
2011 & 8,600 \\
2012 & 19,800 \\
2013 & 21,500 \\
\hline
\end{tabular}

TABLE 1. Number of sold unfired bricks of Heluz company [7].

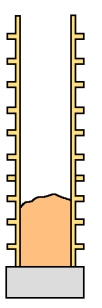

Step 1

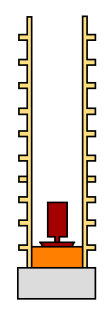

Step 2

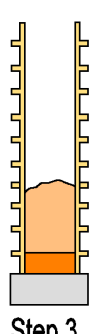

Step 3
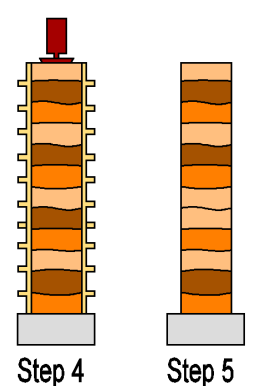

Figure 1. The process of building rammed earth wall.

and clay) is filled in. Secondly, the layer of moist earth is compressed by a pneumatic backfill tamper. Thirdly, next layer of moist earth is added and then succesive layers of moist earth are added and compressed. Finally, the framework is removed leaving the rammed earth wall with visible layers of compacted earth. When dried, the result is a dense, hard monolithic wall $4-6$. 

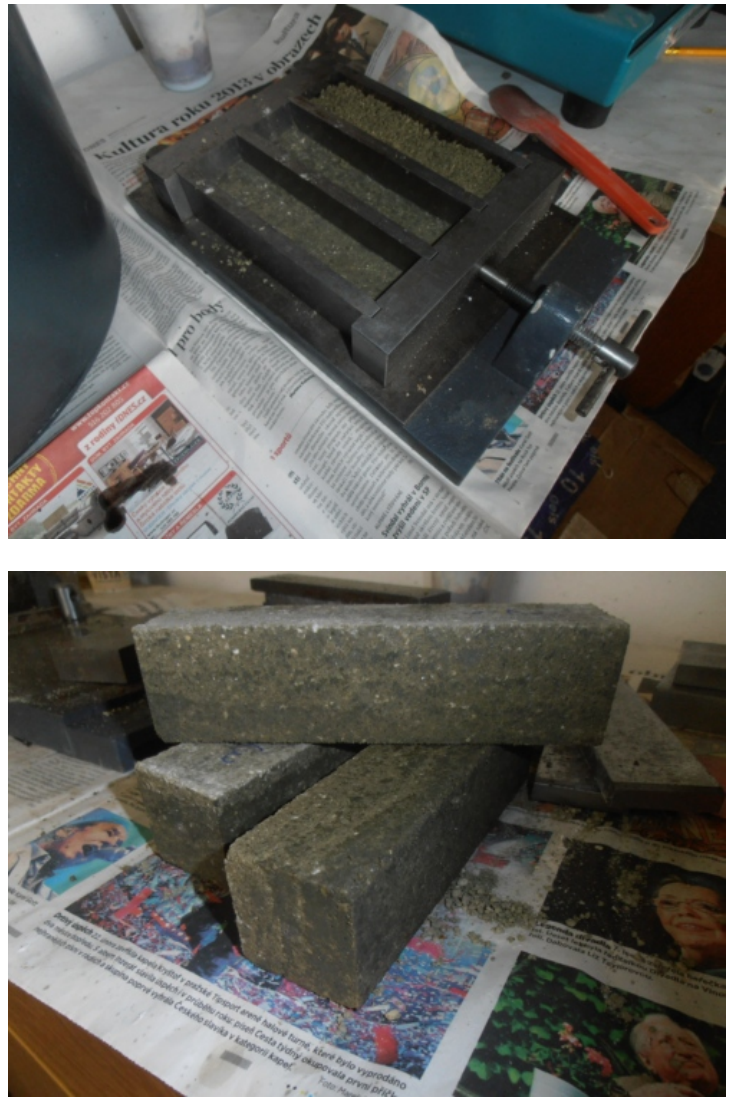

Figure 2. The production of rammed earth specimens.

\section{TESTING OF UNFIRED EARTH MATERIAL}

\subsection{RAMMED EARTH AND WATER}

The rammed earth material is considered for building bearing walls of construction so that the material is often exposed to rain and moisture of external conditions. All materials with open porous structures like loam are able to store and transport water within their capillaries. Water always travels from regions of higher humidity to regions of lower humidity. The value of the water absorption coefficient $w$ is known for common building materials, some of them are shown in Table 2 In the research the value for rammed earth with illite-kaoline clay was searched for to be compared with values of other building materials. The premise was that the value of the water absorption coefficient $w$ for rammed earth would be higher than for common building materials.

\subsection{PREPARING MATERIAL}

Prescriptions for the specimens were designed of clay, sand and water. There were two prescriptions GEM I and GEM II of montmorillonite clay and AGL I and AGL II of illitic-kaolinite clay. Prescriptions I and II differed in the sand/clay ratio. The amount of the components was expressed by the weight percent. The amount of water was settled as a water/clay ratio, same at both prescriptions, all prescriptions are shown in Table 3

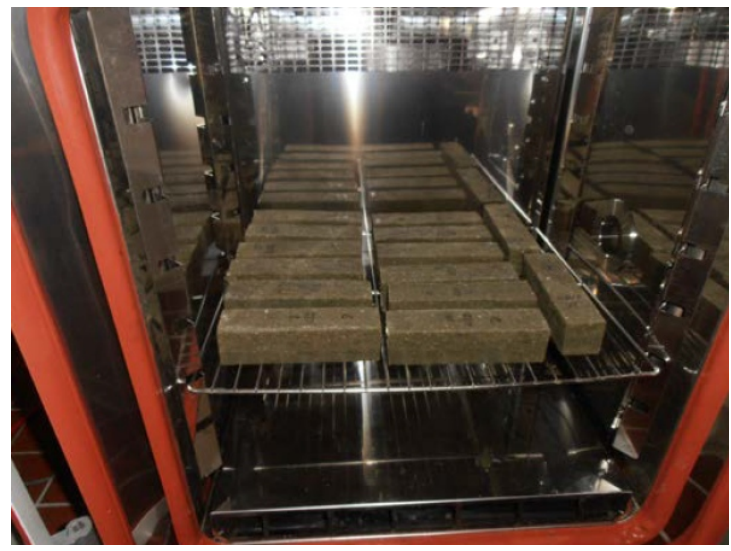

Figure 3. Specimens in the climatic chamber.

\begin{tabular}{lcc}
\hline Material & $\begin{array}{c}w \\
{\left[\mathrm{~kg} / \mathrm{m}^{2} \sqrt{\text { hour }}\right]}\end{array}$ & $\begin{array}{c}\rho \\
{\left[\mathrm{kg} / \mathrm{m}^{3}\right]}\end{array}$ \\
\hline Silty Loam & 3.7 & 1900 \\
Clayer Loam & 1.6 & 1940 \\
Cement Concrete & 1.8 & 2290 \\
Hollow Brick & 8.9 & 1165 \\
Solid Brick & 25.1 & 1750 \\
\hline
\end{tabular}

TABle 2. Water Absorption Capacity Coefficient of common building materials [5].

First of all, the sand was well mixed with two thirds of water. Secondly, the clay and the rest of water was added. It was mingled by a drilling machine with a special ending. Specimens of size $40 \times 40 \times 160 \mathrm{~mm}$ were prefabricated for the testing in the laboratory. The production was made by ramming into moulds by hand and by drilling machine. The moulds were wiped by oil and the earth was rammed in four to five layers. Layers were compresed by a mechanical tamper and the last one was always compresed by hand. Produced specimens are shown in Figure 2

Specimens were tested after four weeks from production. By this time the humidity from the prefabrication is stable and is not changing any more. The hardening process of clay is based only on the drying out the mixed water. During these four weeks the specimens were settled in constant condition of temperature $20{ }^{\circ} \mathrm{C}$ and moisture $50 \%$ in the climatic chamber (specimens in climatic chamber Figure 3 ).

\subsection{Practical tests}

Firstly, specimens were put in the covering of nylon to avoid the erosion of particles from the submerged surface. Secondly, they were weighted and finally settled in the box with soft foam that was moistened. The level of moist was constant, the water was added during the test. The specimens were regularly measured and weighted. Some of the specimens were broken during the test, they were removed from the testing and not evaluated. 


\begin{tabular}{cccccc}
\hline Prescription & Type of used clay & Sand [\%] & Clay [\%] & Water/clay ratio [-] & Bulk density $\left[\mathrm{kg} / \mathrm{m}^{3}\right]$ \\
\hline AGL I & illite-kaoline & 80 & 20 & 0.37 & 2191 \\
AGLII & illite-kaoline & 75 & 25 & 0.37 & 2159 \\
GEM I & montmorillonite & 80 & 20 & 0.37 & 2073 \\
GEM II & montmorillonite & 75 & 25 & 0.37 & 2040 \\
\hline
\end{tabular}

TABLE 3. Prescriptions of used specimens and bulk densities of final specimens.

Twenty specimens of GEM and ten specimens of AGL were tested. The test of GEM was 14 days long and the AGL was evaluated for three hours of the test beginning.

\section{Evaluation of the measurement}

\subsection{MASS MOISTURE DEVELOPMENT}

The mass moisture $m_{w}$ was calculated from measured weigh using relation:

$$
m_{w}=\frac{m-m_{d}}{m_{d}}
$$

The mass moisture $m_{w}$ was calculeted as a weight of the wet specimen $m$ minus the weight of dry specimen $m_{d}$ and then it was divided by the weight of the dry specimen $m_{d}$ (the weight of the specimen in the beginning of the test) and it was multiplied by 100 to transform it to percentage of weight. The data of specimen with different starting weight can be compared with the mass moisture.

The data represented the specimens that were not broken during the whole testing. They had the same conditions at the same time. The mass moisture increase is shown in the Figure 4. The mass moisture in percent is shown on the vertical axis and the time (in hours or days) is shown on the horizontal axis.

\subsection{WATER ABSORPTION CAPACITY COEFFICIENT}

The water absorption cofficient $w$ determines the ability of material absorp water by an area in defined time period. The formula for its calculation is:

$$
w=\frac{W}{\sqrt{t}} .
$$

Units of $w$ are $\mathrm{kg} / \mathrm{m}^{2} \sqrt{t}$. The quantity of water $W$ that can be absorbed by an area $A$ is defined by the formula:

$$
W=\frac{m-m_{d}}{A} .
$$

Units of weight of the wet specimen $m$ and weight of the dry specimen $m_{d}$ are in $\mathrm{kg}$ and the time $t$ is measured in hours.

The weights were measured in a time period of one hour for AGL prescriptions. The absorbing area of specimens is $40 \times 40 \mathrm{~mm}$. The coefficient $w$ was calculated for prescription AGL I and AGL II.
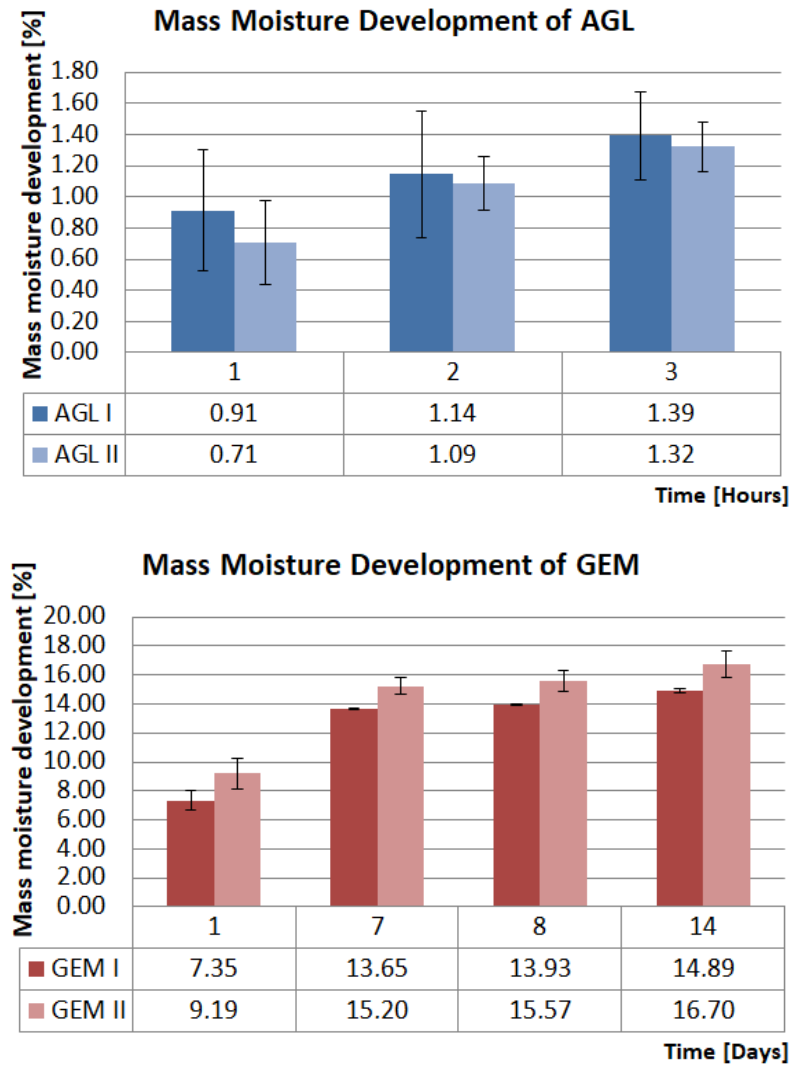

Figure 4. Mass moisture development of prescriptions AGL and GEM.

\section{Discussion}

The mass moisture development of AGL (blue column) and GEM (red column) is shown in Figure 4. The mass moisture development of AGL I rose to $1.39 \pm 0.28 \%$ and of AGL II to $1.32 \pm 0.16 \%$ after four hours. The biggest increase was in the first hour of testing then the mass moisture rose quite slower.

The specimen of GEM I rose to $14.89 \pm 0.13 \%$ and of GEM II to $16.70 \pm 0.92 \%$ after 14 days. The trend of development was simillar to the first measurement, the biggest change was in the first days then it slowed down.

The coefficient $w$ was calculated to $2.80 \pm 0.55 \mathrm{~kg} / \mathrm{m}^{2} \sqrt{t}$ for AGL I and $2.70 \pm 0.30 \mathrm{~kg} / \mathrm{m}^{2} \sqrt{t}$ AGL II. The calculated values were compared to known characteristics of common building materials as it is shown in Figure 5 The coefficients $w$ for two types of loam, cement concrete and two types of bricks were compered to 


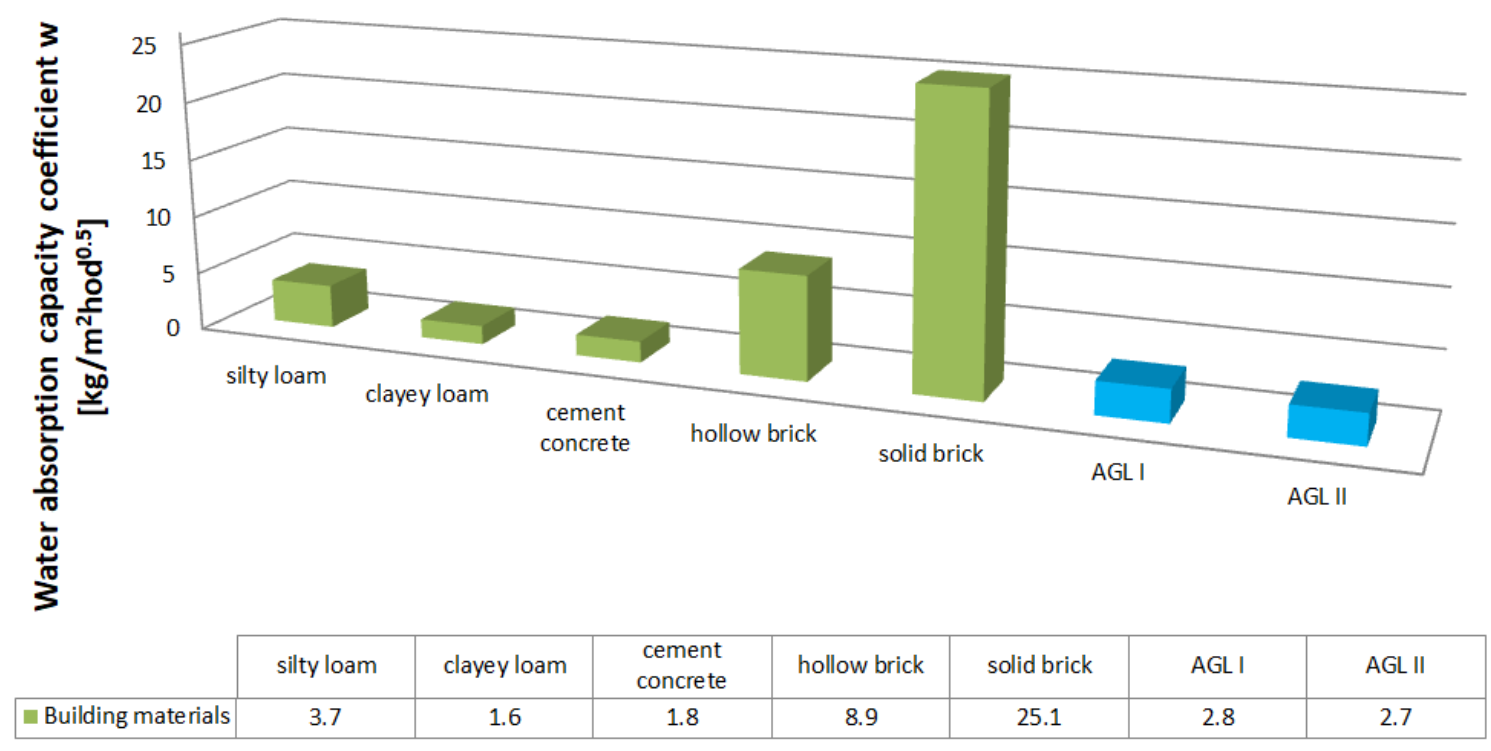

FIGURE 5. Water absorption capacity coefficient of common building materials and tested rammed earth AGL.

illitic-kaolinite rammed earth material. The results of made tests AGL are between the values of silty and clayey loam. The coefficient $w$ for AGL I is only $1.56 \times$ higher than for cement concrete.

The value of AGL I is $0.11 \times$ lower in comparation to the solid brick. The value above $10 \mathrm{~kg} / \mathrm{m}^{2} \sqrt{t}$ is consider to be not so good for building material. Non of the prescriptions exceeds this limit, so in the point of view of the coefficient $w$, the rammed earth material with illite-kaoline clay is competitive to other common building material.

\section{Conclusion}

The rammed earth material properities in relation to mass moisture and water absorption capacity coefficient was observed. Two kinds of specimens were prepared, one prescription of illite-kaoline clay and the other of montmorillonite clay.

The increasing of mass moisture in rammed earth of illite-kaoline clay in three hours and montmorillonite clay in forteen days was observed. The progress of mass moisture increasing was fastest in the beginnig of moistenig for both cases.

The other observed value was the water absorption capacity coefficient $w$ for rammed earth with illite-kaoline clay (prescriptions AGL I and AGL II). The calculated values are comperative to other buiding material as cement concrete and they are according to the values found in literaterature [5] for silty loam and clayey loam. From that point of view, rammed earth have better properities than for example the solid brick.
Generally the calculated values of water absorption capacity coefficient are lower than it was expecting in the begining of the test.

\section{ACKNOWLEDGEMENTS}

This research was financial supported by the Faculty of Civil Engineering at CTU in Prague (SGS project No. 16/201/OHK1/3T/11).

Authors gratfully aknowledge free supply of material necessary for experimental measurement to LB Minerals, s.r.o. company.

\section{REFERENCES}

[1] P. Suske. Hlinené domy novej generacie. First printing. Alfa Bratislava, 1991.

[2] P. Suske. Nepalena hlina v moderni architekture. Dokument ERA21: ekologie, realizace, architektura (2):69-70, 2004.

[3] B. Little, M. Morton. Building with Earth in Scotland: Innovative Design and Sustainability. First printing. Scottish Executive Central Research Unit, 2001.

[4] J. Norton. Building with Earth, A Handbook. First printing. Intermediate Technology Development Group Limited, 1986.

[5] G. Minke. Building with Earth - Design and Technology of Sustainable Architecturer. Second printing. Birkhauser Publishe, 2006.

[6] I. Zabickova. Hlinene stavby. First printing. Era vydavatelstvi, 2002.

[7] I. Zabickova, T. Otcovska. Compressive strength of unburned clay masonry. Applied Mechanics and Materials pp. 31-34, 2016. 